\title{
18. ABYSSAL FELDSPATHIC SEDIMENTS IN THE NORTHWESTERN PACIFIC
}

\author{
Hakuyu Okada, Department of Geology, Kagoshima University, Kagoshima 890, Japan
}

\section{INTRODUCTION}

Feldspar-rich, coarse-grained sediments were frequently found in the abyssal deposits sampled at Deep Sea Drilling Project Leg 20 sites in the northwestern Pacific. These feldspathic sediments correspond to feldspathic arenite according to Okada's scheme of sandstone classification (Okada, 1971). These sediments are quite interesting in that sedimentary rocks of similar composition are often found in ancient geosynclinal deposits, e.g., in the Yezo geosyncline, Japan (Okada and Nakao, 1968) and Tasman geosyncline, Australia (K.A.W. Crook, personal communication and my own observation).

In this paper, the petrological characteristics of feldspar-rich sediments of Hole 199 are described and are compared with feldspathic sedimentary rocks of ancient geosynclines. Some comments are also given on the geological significance of these characteristic sediments.

\section{PHYSIOGRAPHIC AND GEOLOGIC SETTINGS}

Site 199 , at lat $13^{\circ} 30.78^{\prime}$ N., long $156^{\circ} 10.34^{\prime} \mathrm{E}$., is located at the east margin of the Caroline Abyssal Plain north of Caroline Islands.

The cored section at Site 199 is subdivided lithologically into two sequences. The upper sequence, about 210 meters thick, consists of brown clay characterized by the presence, in significant amounts, of reworked microfossils as well as by sporadic occurrence of small fragments of fine sand and silt. These sediments may have been deposited under the influence of turbidity currents and slumping. The age of this sequence ranges from Middle Miocene to Pliocene or younger. The lower sequence, Campanian to Paleocene in age, consists mainly of chalk and limestone interlayered with chert and tuff.

\section{SEDIMENTARY FEATURES OF FELDSPATHIC SEDIMENTS}

\section{Occurrence}

Feldspathic sediments occur in brown clay mostly as small fragments of irregular form and infrequently as apparently interlayered thin beds (a few centimeters thick). Foraminifer-bearing nannofossil ooze frequently occurs together with these fragments, as irregular patches.

Figure 1 shows an example of the occurrence of the feldspathic sediments.

\section{Sedimentary Structures}

Most fragments show clearly either parallel- or cross-laminae as internal sedimentary structures. The best example of well-developed parallel lamination is observed in the material sampled at 87 to $91 \mathrm{~cm}$ of Hole 199, Core 2, Section 6 (Figure 2). This structure is composed of

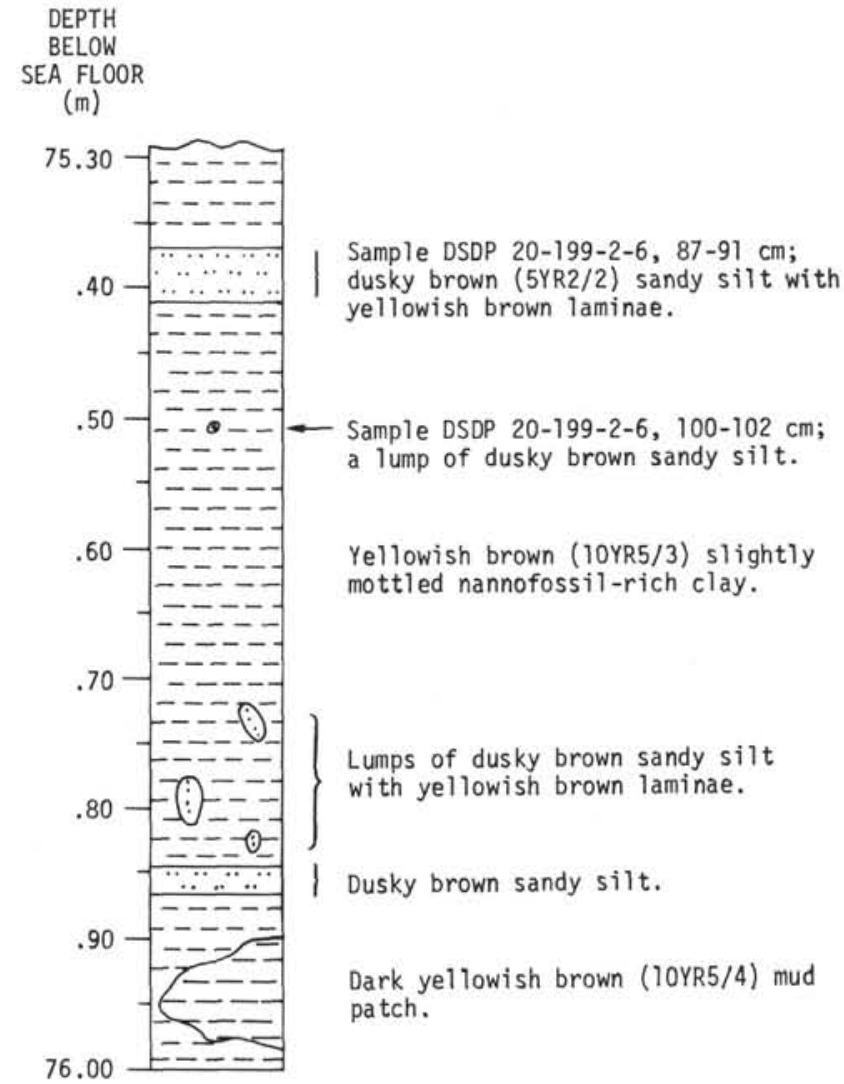

Figure 1. Occurrence of feldspathic sediments (dotted parts) in Site 199 (Core 2, Section 6).

yellowish brown (10YR 6/2) and dusky brown (5YR 2/2) layers. Thickness of the former layers varies up to $4 \mathrm{~mm}$. Although grading is not clear in the thick layers, their lower boundary is fairly sharp, and micro-flame structure is observable (Figure 2).

The present sediments are more or less indurated and well defined from the surrounding clay.

\section{Texture}

Textural features of DSDP 199,2,6 (87-91 cm) were examined (Figure 2). The following samples were prepared for grain-size analysis: one (Sample IV) from the dark-colored layer (medium gray, N5, on the dried surface) and two others (Samples I and II) from the pale-colored layers (light gray, N7, on the dried surface). Samples I, II, and IV represent a $2.5 \mathrm{~mm}$-thick layer, $4.5 \mathrm{~mm}$-thick layer, and $2.5 \mathrm{~mm}$-thick layer, respectively. The grain-size analysis data for these samples, in which Inman's graphic method was introduced for determination of size-distribution parameters, are shown in Table 1. 


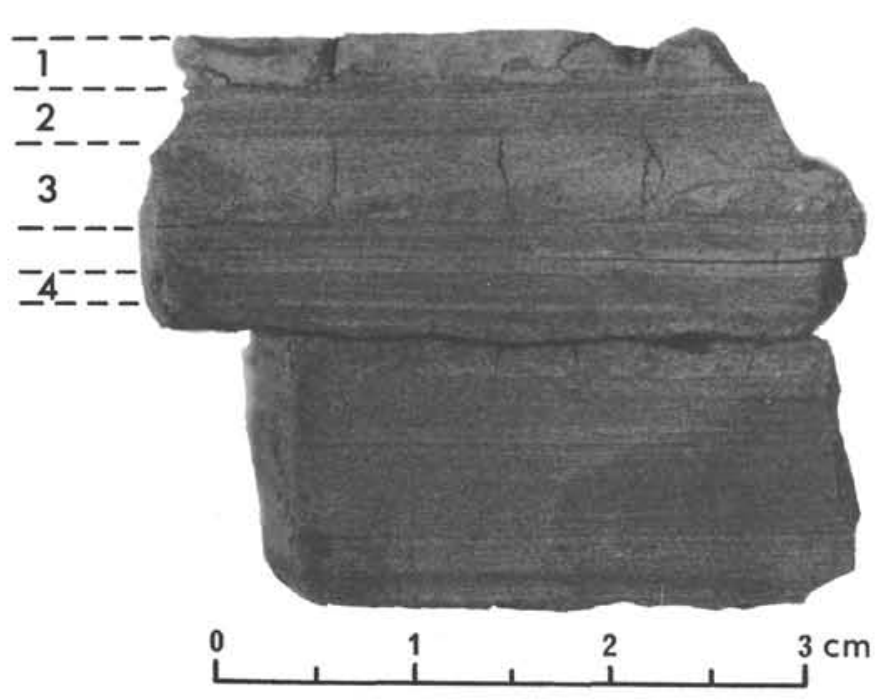

Figure 2. Internal sedimentary structures and positions of the petrological samples listed in Tables 1 and 2.

The result seems to show no significant textural difference between the pale-colored and dark-colored layers.

\section{PETROLOGY}

\section{Petrological Samples and Procedure}

Five petrological samples (I through V in Table 2) were prepared. Samples I through IV came from DSDP 199,2,6, $87-91 \mathrm{~cm}$ (Figure 2) and Sample V from an isolated small lump of fine sand in yellowish brown (10YR 5/3) nannofossil-rich clay of DSDP 199,2,6, 100-102 cm (Figure 1).

In petrological examinations, 300 to 400 grains were identified and counted on each slide using a polarizing microscope with a mechanical stage. A few selected samples were run on an X-ray diffractometer.

\section{Mineral Composition}

Mineral compositions of sand and silt are presented in Table 2. Feldspar, iron opaques, palagonite, clinopyroxene, and volcanic glass are the major constituents of the

TABLE 1

Grain-size Data of the Feldspathic Sediments from Site 199

\begin{tabular}{lrrr}
\hline & {$[\mathrm{I}]$} & {$[\mathrm{II}]$} & \multicolumn{1}{c}{$[\mathrm{IV}]$} \\
\hline $\mathrm{Md} \phi$ & 3.25 & 3.70 & 3.60 \\
$\mathrm{M} \phi$ & 3.07 & 3.50 & 3.33 \\
$\sigma \phi$ & 0.78 & 0.55 & 0.67 \\
$\mathrm{Sk} \phi$ & -0.23 & -0.36 & -0.40 \\
\hline Legend: \\
{$[\mathrm{I}]:$} & From (1) in Figure 2; Sam- \\
& ple 199, 2, 6 (87-91 cm). \\
{$[\mathrm{II}]:$} & From (3) in Figure 2; Sam- \\
& ple 199, 2, 6 (87-91 cm). \\
{$[\mathrm{IV}]:$} & From (2) in Figure 2; Sam- \\
& ple 199, 2, 6 (87-91 cm).
\end{tabular}

examined samples; of these feldspar is always predominant (see Figure 3).

Feldspar and calcite are more concentrated in the light gray than in the dark gray laminae, while opaque matter shows an opposite trend.

Feldspar is represented by plagioclase grains, which are mostly fresh. Some grains are euhedral in shape, but zonal features were hardly detected. Albite and albite-Carlsbad twinning is often present. According to the extinction-angle method, the approximate composition of plagioclase falls in $\mathrm{An}_{38-50}$. Refractive indices of plagioclase were also determined by the immersion method as $n_{1} \mathrm{~min}=1.530$ and $n_{2} \max =1.555$, which indicates a composition of $\mathrm{An}_{4-40}$ according to Chayes's (1952) chart. Both of these data suggest that the plagioclase is acidic to intermediate in composition.

Grains which show various shades of bright yellowish to reddish brown colors and isotropic natures or weak birefringence, are defined as palagonite. These grains are sporadically found in most of the samples.

Clinopyroxene occurs in either granular or prismatic form. The grains usually present yellowish green color and strong birefringence.

Volcanic glass is mostly fresh and colorless, being acidic to intermediate in composition. Zeolites occur as slender euhedral laths mostly with ragged margins, although specific identification was impossible. Most calcite grains occur as fragments of sparry calcite, while a few occur as aggregates of microcy rstalline form.

\section{DISCUSSION}

It is reported that bottom sediments of oceans and shelf seas, not restricted to particular geographic areas, contain

TABLE 2

Mineral Composition of Sand and Silt Fractions from Site 199a

\begin{tabular}{lcccccc}
\hline & \multicolumn{3}{c}{ Light Gray } & \multicolumn{5}{c}{ Dark Gray } \\
& Layers & & Layers & \\
\multicolumn{1}{c}{ Components } & {$[\mathrm{I}]$} & {$[\mathrm{II}]$} & {$[\mathrm{III}]$} & {$[\mathrm{IV}]$} & {$[\mathrm{V}]$} & [VI] \\
\hline Feldspar & 66.5 & 71.7 & 60.3 & 61.4 & 49.3 & \\
Volcanic glass & 2.6 & 2.8 & 1.1 & 1.0 & 1.4 & \\
Zeolite & + & + & 1.4 & 4.6 & + & \\
Calcite & 7.5 & 5.6 & 1.8 & 3.4 & - & \\
Foraminifera fragments & + & - & - & 1.0 & - & \\
Diatom fragments & + & - & - & - & - & \\
Palagonite & 9.8 & 6.8 & 13.5 & 3.4 & 12.4 & \\
Iron opaques & 9.8 & 12.4 & 20.3 & 19.2 & 27.6 & 51.7 \\
Clinopyroxene & 1.9 & + & 1.4 & 3.7 & 8.8 & 48.2 \\
Rutile & + & - & + & + & + & + \\
Biotite & - & - & - & + & - & + \\
\hline
\end{tabular}

a Size of grains ranges from 30 to 150 microns. 300 to 400 grains were counted on each slide.

Legend:

"+": less than 1 percent and "-_": not detected.

[I] : From (1) in Figure 2; Sample 199,2,6 (87-91 cm).

[II] : From (3) in Figure 2; Sample 199,2,6 (87-91 cm).

[III] : From (4) in Figure 2; Sample 199,2,6 (87-91 cm).

[IV]: From (2) in Figure 2; Sample 199,2,6 (87-91 cm).

[V]: From a very fine-grained sand lump $(5 \mathrm{~mm} \times 3 \mathrm{~mm} \times 3 \mathrm{~mm})$, Sample 199,2,6 (100-102 cm).

[VI] : Heavy minerals from a mixture of [III] and [IV]; the amount of heavy minerals is 23.3 percent in weight. 


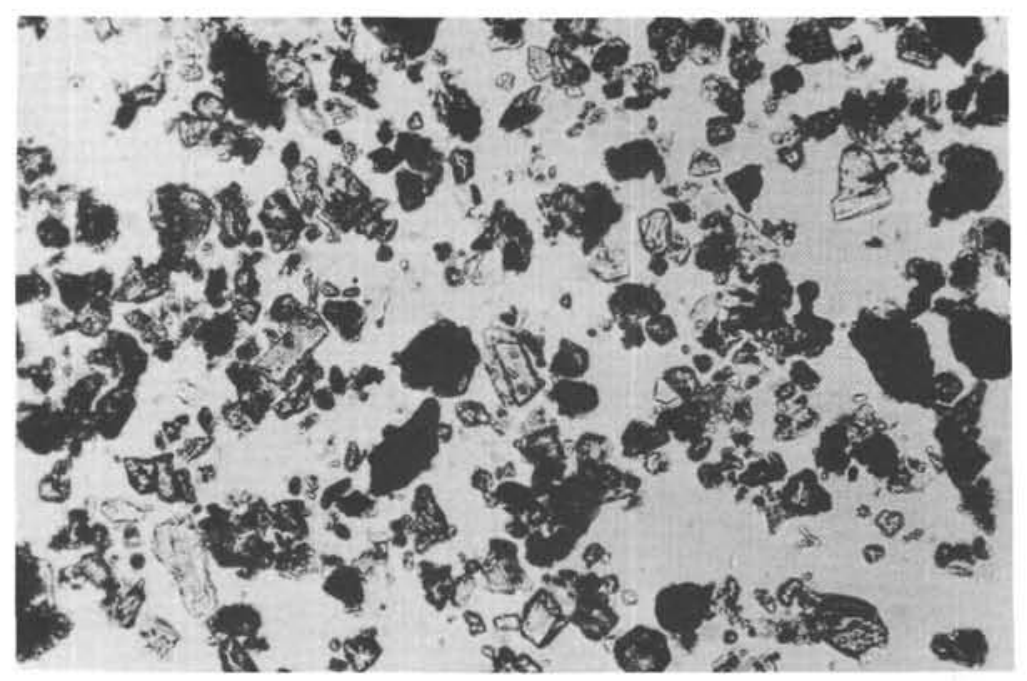

Figure 3. Photomicrograph of the dark gray layer (fourth layer in Figure 2) composed mainly of iron opaques, plagioclase, and clinopyroxenes. Open nicols; $\times 150$.

significant amounts of feldspars (e.g. Peterson and Goldberg, 1962; Field and Pilkey, 1969; Heath, 1969; Vallier, 1970; etc.). Feldspars in shelf sediments and turbidites found beyond the shelf edge are derived as a rule from continents or nearby high-relief land masses, as reported by Field and Pilkey (1969) and Vallier (1970), and for equatorial Pacific pelagic sediments with concentrations of feldspars, wind-transported continental debris was inferred to be the source of feldspars (Heath, 1969). However, Peterson and Goldberg (1962) concluded that feldspars from pelagic sediments of the South Pacific are of volcanic origin and were derived mostly from within the basin itself.

Judging from the mineral association, the feldspathic sand and silt herein examined are volcanogenic. The constituent minerals of the present sediments may have been sorted by traction currents at sites of original deposition to form parallel- or cross-laminae, but the original thickness of these deposits is not known.

The fact that the sediments occur mostly as fragments together with patches of reworked nannofossils and foraminiferal ooze suggest that they were brought down to greater depths by slumping, probably from above the calcium carbonate compensation depth. Their ultimate source may have been acidic to intermediate volcanics of nearby island arcs because, in contrast with the plagioclase crystals now in question which indicate acidic to intermediate composition, Neogene volcanic glasses from the same core as the present material are dominantly basaltic (Jones and Bowles, 1971, in this volume).

Sediments of this type are quite comparable to. feldspathic sandstone in ancient geosynclines. A good example of the latter is plagioclase arenite or plagioarenite in the Cretaceous Yezo geosyncline of Hokkaido, Japan (see Okada and Nakao, 1968).

The plagioarenite in the Lower Cretaceous Lower Yezo Group, which overlies conformably the Lower Cretaceous to Jurassic Sorachi Group, is composed of radiolarian chert and siliceous shale, basic tuff, and diabase intrusions. The Lower Yezo Group is characterized by a turbidite sequence indicating flysch facies. In the lower part of the Group, displaced "Orbitolina" limestone bodies are also found.

The plagioarenite layers are intercalated in the shaly sequence of the Lower Yezo Group. They are less than 15 $\mathrm{cm}$ in thickness and are current sorted. Some layers show graded bedding. Plagioclase grains constitute more than 80 percent of the whole clastics in these rocks. Plagioclase composition falls within the range of $\mathrm{An}_{21-39}$. Plagioarenite of similar nature is frequently found in other sequences of the Yezo geosyncline.

It is interesting that plagioclase of both the modern deep-sea sediments and the ancient geosynclinal deposits is characterized by acidic to intermediate compositions.

\section{CONCLUSION}

Feldspathic sediments from the abyssal floor have many characteristics in common with ancient feldspathic sedimentary rocks in petrological nature as well as occurrence. Acidic to intermediate volcanic activity may have been important in the formation of these sediments. Such examples from modern sediments could be important in furthering out knowledge of the development of geosynclines.

\section{REFERENCES}

Chayes, F., 1952. Relations between composition and indices of refraction in natural plagioclase. Am. J. Sci., 85.

Field, M. E. and Pilkey, O. H., 1969. Feldspar in Atlantic continental margin sands off the southeastern United States. Bull. Geol. Soc. Am., 80, 2097. 
Heath, G. R., 1969. Mineralogy of Cenozoic deep-sea sediments from the equatorial Pacific Ocean. Bull. Geol. Soc, Am. 80, 1997.

Okada, H., 1971. Classification of sandstone: Analysis and proposal. J. Geol. 79, 509.

Okada and Nakao, S., 1968. Plagioclase arenite in Lower Cretaceous flysch in the Furano area, Hokkaido. J. Geol. Soc. Japan. 74, 451.
Peterson, M. N. A. and Goldberg, E. D., 1962. Feldspar distributions in South Pacific pelagic sediments. J. Geophys. Res. 67, 3477 .

Vallier, T. L., 1970. The mineralogy of some turbidite sands from Sites 32 and 35. In McManus, D. A., Burns, R. E. et al., 1970. Initial Reports of the Deep Sea Drilling Project, Volume V. Washington (U. S. Government Printing Office) 535. 